\title{
Descriptive Analysis of Epidemiological Profile from Authors of Civil Claims Due to Supposed Medical Malpractice Against Neurosurgeons In Brazil
}

\section{Análise descritiva do perfil epidemiológico dos autores de ações cíveis motivadas por suposto erro médico contra neurocirurgiões no Brasil}

\author{
Leandro Pretto Flores $^{10}$ Walduy Fernandes de Oliveira ${ }^{2}$ \\ ${ }^{1}$ Clínica de Neurocirurgia, Hospital das Forças Armadas, Brasília, DF, Brazil \\ ${ }^{2}$ Sociedade Brasileira de Direito Médico e Bioética, Brasília, DF, Brazil \\ Address for correspondence Leandro Pretto Flores, MD, PhD, SHIN QL \\ 07 Conjunto 01 Casa 18, Brasília, DF 71515-015, Brazil \\ Arq Bras Neurocir 2020;39(2):68-78. \\ (e-mail: leandroprettoflores@hotmail.com).
}

\author{
Abstract \\ Keywords \\ - medical malpractice \\ - neurosurgery \\ - civil action \\ - justice \\ - accountability
}

Introduction The neurosurgical practice often involves situations that require rapid and immediate decision making, and a very low margin for error may eventually lead to an unsatisfactory clinical outcome. Thus, neurosurgery is considered as a medical specialty with high risk for the occurrence of litigation for supposed malpractice. The main objective of the present study was to identify the most prevalent epidemiological profile of the authors of civil claims for alleged malpractice against neurosurgeons, as well as to identify the legal strategies most commonly employed in this type of lawsuit. Methods This is a descriptive, retrospective and quantitative study, with review of the initials/exordials of all civil actions motivated by alleged malpractice against neurosurgeons, defended by an office specialized in Medical Law, from 2008 to 2018. Data were collected relative to the author of the action; the disease that led to the outbreak of the action; and some legal information of interest for the outcome of the litigation. Results During the period studied, 16 compensation/eviction claims were identified as being motivated by supposed neurosurgical malpractice. The average age of the authors was 51 years old; with a high school or undergraduate level of education in $75 \%$ of the cases, and especially from the Class B social extract (43\%). Degenerative affections of the lumbar spine (12 cases, $75 \%$ ) were the most common diseases that motivated the litigation, followed by brain tumors ( 2 cases, $12.5 \%$ ), 1 case of carpal tunnel syndrome, and 1 case of chronic pain due to inflammatory radiculitis. The average value of the sponsored claim was $649,000.00$ reais. Justice gratuity was granted in $80 \%$ of the cases and the reversal of the burden of proof by $30 \%$. The main documentary evidence was medical reports - from third parties or the surgeon him/herself, and medical records. received

August 18, 2019

accepted

September 30, 2019
DOI https://doi.org/

$10.1055 / \mathrm{s}-0039-3400506$. ISSN 0103-5355.
Copyright $\odot 2020$ by Thieme Revinter

Publicações Ltda, Rio de Janeiro, Brazil
License terms

(c) $(1) \$$ 


\section{Resumo}

\author{
Palavras-chave \\ - erro médico \\ - neurocirurgia \\ - ação cível \\ - justiça \\ - culpa
}

Conclusions The number of civil claims against neurosurgeons has been increasing dramatically over the past decade. The results of the present study may be useful to health professionals and law offices specialized in professional defense to identify some more effective measures regarding the prevention of potential litigation, in spite of the identification of the most common personal profiles that end up proposing a process of civilian repair against neurosurgeons.

Introdução A prática do neurocirurgião frequentemente o envolve em situações que requerem uma tomada de decisão rápida e imediata, com baixíssima margem para erro, cujos potenciais efeitos adversos podem incorrer em um desfecho clínico insatisfatório. Assim, a neurocirurgia é considerada uma especialidade de alto risco para a ocorrência de processos por suposto erro médico. O presente estudo tem como principal objetivo identificar o perfil epidemiológico mais prevalente de autores de ações cíveis por suposto erro médico contra neurocirurgiões, além de identificar as estratégias jurídicas mais comumente empregadas neste tipo de ação judicial.

Métodos Trata-se de um estudo descritivo, retrospectivo e quantitativo, com revisão das exordiais de todas as ações cíveis motivadas por suposto erro médico contra neurocirurgiões, defendidas por uma banca de advocacia especializada em Direito Médico, no período de 2008 a 2018. Foram coletados dados relativos ao autor da ação; à doença que motivou a deflagração da ação; e algumas informações de cunho jurídico de interesse para o desfecho do litígio.

Resultados No período estudado, foram identificados 16 processos de ações civis de indenização/reparação movidas contra neurocirurgiões motivadas por suposto erro profissional. A idade média dos autores foi de 51 anos, com grau de instrução superior ou médio em $75 \%$ dos casos, procedentes em especial do extrato social de Classe $B$ (43\%). As doenças que motivaram a ação foram: patologias degenerativas, traumáticas e infecciosas da coluna vertebral lombar (12 casos, 75\%), tumores cerebrais ( 2 casos, 12.5\%), 1 caso de síndrome do túnel do carpo, e 1 caso de dor crônica. O valor médio da pretensão indenizatória foi de $649.000,00$ reais. Gratuidade de justiça foi concedida em $80 \%$ dos processos e a inversão do ônus da prova em $30 \%$. As principais provas documentais apresentadas foram o prontuário médico (ou partes deste) e relatórios médicos formulados seja pelo próprio profissional requerido, seja por terceiros.

Conclusões O número de ações cíveis de reparação de danos contra neurocirurgiões vem aumentando consideravelmente na última década. Os resultados do presente estudo podem ser úteis aos profissionais de saúde e escritórios de advocacia especializados na defesa profissional no sentido de identificar medidas mais efetivas quanto à prevenção de potenciais litígios judiciais, no que pese na identificação dos tipos mais comuns que acabam por propor um processo de reparação cível contra neurocirurgiões.

\section{Introduction}

Conceptually, medical malpractice, or only malpractice, corresponds to an unintentional injury caused by an action or omission of a physician during the exercise of his/her profession. This definition proves to be completely different from the concept of "complication", since the latter is characterized by an event inherent to the medical act, but without any connection with an action that may be considered reckless, negligent or imperfect. Medical malpractice can lead to civil sued, which occurs when the patient or his/her relatives demand varied reparations to justice due to an alleged error ${ }^{1}$ in face of the diagnosis or treatment offered. For the accused physician, the costs of such a judicial action are numerous and are not only limited to financial losses, but also indirect losses such as time, depression, fatigue, stress, reputation damage, reduced satisfaction with the career, alcohol/drug abuse, as well as rising of suicide rates. ${ }^{2}$ In addition, in cases involving surgical treatments, patients themselves and society in general also end 
up with a cost, as many of the surgeons prosecuted end up adopting practices called as Defensive Medicine, such as avoiding high-risk surgery, or increasing the number of procedures (laboratory and imaging tests, excessive use of medications) to delay the effective decision-making by surgery, which can compromise the outcomes and increase the costs of the treatments. ${ }^{3}$

Updated data from the literature indicate that in Brazil, every year, $\sim 7 \%$ of all physicians are sued. ${ }^{4}$ Considering an universe of 470,855 doctors currently active, we can easily conclude that more than 30,000 new lawsuits against physicians are initiated annually. The likelihood of being sued depends on the specialty of the professional. The cumulative risk of facing medical malpractice claims until the age of 65 is $\sim 70 \%$ for professionals with more generalist specialties such as pediatrics, medical clinics, family medicine; while it is close to $99 \%$ in high-risk specialties, including neurosurgery. ${ }^{5}$ The neurosurgeon basically works with very delicate anatomical structures and, for this reason, his activity is considered of high risk for development of complications and, sometimes, unsatisfactory outcomes. Since the second half of the $20^{\text {th }}$ century, neurosurgery has been developing a more sophisticated and less invasive technical arsenal, precisely to reduce the risks involved in surgical procedures and also to decrease the chance of unexpected negative events. However, since the daily practice often involves the neurosurgeon in situations that require some quick and immediate decision-making, with very low margin for error, the potential adverse effects of these actions may eventually trigger an unsatisfactory clinical outcome. Due to all these peculiarities, neurosurgery is considered a high-risk specialty for the occurrence of claims for alleged medical malpractice. ${ }^{6}$

The Brazilian Superior Court of Justice (STJ, in the Portuguese acronym) analyzed, in 2014, 626 cases of medical malpractice, of which $7.14 \%$ were related to civil claims against neurosurgeons. ${ }^{4}$ At the level of the Federal District (DF, in the Portuguese acronym), data from the Federal District Court (TJDF, in the Portuguese acronym) indicate that between 2013 and 2015, 10 claims were filed against neurosurgeons, totaling $5 \%$ of a total of 202 cases $^{7}$ filed at that court. Higher Courts data indicate that, compared with the beginning of the decade, in 2018 there was a nearly $250 \%$ increase in the number of litigations filed against medical physicians.

The main reasons that lead to this increase in the number of legal actions for reparation of damages can be summarized as follows: a) greater access to justice, especially with the facility of gratuitous justice, in which the act of prosecuting the physician practically renders null the risk to the patient; b) the reduction of the quality of the offered medical service, whether due to questions related to the training of the professional or related to the scrapping of the Brazilian health infrastructure; c) an increase in the number of legal professionals who facilitate access to justice, even though the professional is often aware of the low prospect of success in the action (the so-called "malpractice industry"); d), and finally, but perhaps most importantly, questions related to the patient itself, since they have become more informed, more demanding and, therefore, less tolerant. ${ }^{8}$ Moreover, modern societies are increasingly demanding of people who, whenever something does not completely meet their personal expectations, seeks for a guilty party. And, many times, in the search for this culprit, the patient confuses the frustration of his expectations with an alleged medical error.

American authors point out that one of the main reasons for the increase in the number of claims against physicians in the USA stems from the belief of the population that almost all health events can be controlled or even resolved. Therefore, the occurrence of unusual, unsatisfactory or unexpected outcomes ends up becoming a fertile field for litigation. ${ }^{9}$ Currently, we note with concern the growing increase in civil damages actions for alleged malpractice against neurosurgeons in Brazil. The current situation forces us to question whether this increasing number of processes is effectively a result of a decrease in the quality of professional care, that is, a real increase in the failures; or would it correspond only to a modern phenomenon intermediated by subliminal mechanisms (such as media induction) associated with a behavioral change in society as a whole, in the sense that it has become less and less tolerant about the limitations of medicine itself, and more demanding about its expectations regarding the methods of therapeutic intervention currently available.

The main objective of the present study was to identify the most prevalent epidemiological profile of authors of civil claims for alleged malpractice against neurosurgeons, in addition to trying to identify the legal strategies most commonly employed in this type of claim. To achieve this objective, we analyzed the epidemiological aspects of the individuals who decided to sue neurosurgeons, as well as some characteristics of the diseases that led to the outbreak of the litigation. Finally, the objective is to evaluate the way in which the case was initially conducted by the lawyers of the requesting party and also by the magistrate himself. The results of the present study may be useful for health professionals and law offices specialized in medical defense to identify some more effective measures in the prevention of potential litigation, in spite of the identification of the most common types that end up proposing a reparation process against neurosurgeons, in addition to assisting these professionals at the time of their eventual defense.

\section{Methods}

This is a descriptive, retrospective and quantitative study.

We conducted a review of the initials/exordial of all civil actions motivated by alleged medical malpractice against neurosurgeons defended by an office specialized in medical law. It is the Brazilian Society of Medical and Bioethical Law (ANADEM, in the Portuguese acronym), which corresponds to a civil society of an associative nature, with legal personality of private law and national action, which promotes debates on the problems related to the practice of medicine in Brazil. The ANADEM is the promoter and manager of the Professional Lender Protection Fund (FUMDAP, in the Portuguese acronym), which provides professional legal protection through accredited law offices to more than 27,000 
doctors and other Brazilian health professionals. The ANADEM/FUMDAP counts on attorneys specialized in medical professional defense and is frequently activated by its members in case of allegations of professional error, in the administrative, ethical, criminal and civil courts.

Data collection was document type, being performed an analysis of the initials/exordial of civil actions by supposed malpractice moved against neurosurgeons in all of Brazil, in a period of 10 years, that is, 2008 to 2018 . Data was collected regarding the author of the action itself; the illness and the effective treatment that motivated the outbreak of the action; and some legal information of interest for the outcome of the demand.

Thus, the data related to the author of the action were: age, gender, marital status, education, profession and socioeconomical level. As for the disease, the diagnosis itself and the type of treated neurosurgical disease were analyzed, that is, a classification that divides these illness in some large nosological groups, such as follows: tumor (i.e., neoplasia affecting the central nervous system), vascular diseases (those involving veins and cerebral arteries, such as stroke, cerebral aneurysms, etc.), spine (degenerative, infectious and traumatic diseases involving the spine), peripheral nerves (diseases involving the peripheral nervous system), pediatric (neurological disorders in children treated surgically), functional (neurological functional nature diseases, such as Parkinson disease, epilepsy, chronic pain, etc.) and traumatic brain injury. In addition, this topic also evaluated the concrete reasons that led to the outbreak of civil action, that is, basically the complaints or accusations reported by the applicants. Finally, some data concerning legal issues were also evaluated, which are considered important when presenting the exordial and that may interfere in the delineation of the cause. Thus, information regarding the value of the case was collected; whether or not there was a reversal of the burden of proof; whether or not the benefit of gratuitousness of justice was granted to the author; whether the author/applicant submitted a technical assistant; if there were any co-defendant(s) in the same action; if specialized medical expertise was requested; and, finally, what were the documentary evidences attached to the exordial used to prove the narrated facts.

These data then led us to an individualized analysis of each variable in its quantitative aspect, favoring the description of the frequency and constancy patterns of each one. Finally, the global evaluation of the results obtained from the association between variables made it possible to identify the epidemiological profiles of the highest prevalence among the authors of litigations for alleged malpractice against Brazilian neurosurgeons.

\section{Results}

In the period under study, 16 civil lawsuits for compensation/reparation actions were identified against neurosurgeons motivated by supposed professional error. The names of the applicants and of the defendants were kept secret for obvious reasons. From each process, the initials or exordials were extracted from the applicant for the purpose of collecting the specified data, which were summarized in -Tables 1, 2 and 3. It is noted that in two cases the applicant did not correspond to the individual that had undergone the treatment, since in both cases the patient died and the action was moved by a relative.

It was observed that the average age of the authors of these actions was 51 years old, ranging from 27 to 67 years

Table 1 Data Regarding The Authors $(n=16)$

\begin{tabular}{|l|l|l|l|l|l|l|l|}
\hline Case & Year & Age (years old) & Gender & Marital status & Profession & Education & Socio-economic Level \\
\hline $\mathbf{1}$ & 2008 & 55 & Female & Married & Secretary & Superior & B \\
\hline $\mathbf{2}$ & 2009 & 57 & Male & Married & Lawyer & Superior & A \\
\hline 3 & 2010 & 55 & Female & Widower & Public Servant & Superior & B \\
\hline 4 & 2012 & Ignored & Male & Married & Banker & High School & B \\
\hline 5 & 2015 & 51 & Female & Married & Janitor & Basic & D \\
\hline 6 & 2015 & 56 & Male & Married & Phone Technical Staff & High School & C \\
\hline $\mathbf{7}$ & 2015 & 50 & Female & Married & None & Basic & B \\
\hline $\mathbf{8}$ & 2016 & 63 & Female & Married & Ignored & Ignored & Ignored \\
\hline $\mathbf{9}$ & 2016 & 49 & Male & Married & Retired & Illiterate & D \\
\hline 10 & 2016 & 54 & Female & Widower & Ignored & Ignored & Ignored \\
\hline 11 & 2017 & 50 & Male & Married & Security & Basic & C \\
\hline 12 & 2017 & 67 & Female & Married & Professor & Superior & B \\
\hline 13 & 2017 & 50 & Female & Married & Professor & Superior & B \\
\hline 14 & 2017 & 27 & Female & Divorced & Secretary & High School & C \\
\hline 15 & 2018 & 57 & Male & Married & Public Servant & High School & B \\
\hline 16 & 2018 & 37 & Male & Single & Police Officer & Superior & B \\
\hline
\end{tabular}


Table 2 Data Regarding The Desease $(n=16)$

\begin{tabular}{|c|c|c|c|}
\hline Case & $\begin{array}{l}\text { Type of } \\
\text { desease }\end{array}$ & $\begin{array}{l}\text { Etiological } \\
\text { classification }\end{array}$ & Reason \\
\hline 1 & Tumor & Pituitary tumor & Unexpected negative outcome: stroke, permanent disability \\
\hline 2 & Spine & Lumbar spinal stenosis & $\begin{array}{l}\text { Treatment considered incorrect, multiple surgeries, worsening of symptoms, } \\
\text { CSF leak, prosthesis failures. }\end{array}$ \\
\hline 3 & Tumor & Brain glioma & Unexpected negative outcome: marital death \\
\hline 4 & Spine & $\begin{array}{l}\text { Lumbar disk herniation } \\
\text { and spinal stenosis }\end{array}$ & Failure to solve the symptoms, wound infection \\
\hline 5 & Spine & Lumbar disk herniation & worsening of symptoms, novel motor deficit \\
\hline 6 & Spine & Lumbar disk herniation & $\begin{array}{l}\text { Symptoms worsening, no formal contract, insuficient info about risks, } \\
\text { multiple surgeries, CSF leak. }\end{array}$ \\
\hline 7 & Spine & Lumbar spinal stenosis & Worsening of symptoms, multiple surgeries, prosthesis failure \\
\hline 8 & Nerve & Carpal tunnel syndrome & Novel motor deficit \\
\hline 9 & Functional & $\begin{array}{l}\text { Chronic pain: Lumbar } \\
\text { inflammatory radiculitis }\end{array}$ & $\begin{array}{l}\text { Failure to solve the symptoms, multiple surgeries, } \\
\text { treatment considered incorrect. }\end{array}$ \\
\hline 10 & Spine & Lumbar disk herniation & CSF Leak, multiple surgeries, novel motor deficit, worsening of symptoms. \\
\hline 11 & Spine & Lumbar disk herniation & Failure to solve the symptoms, worsening of symptoms, novel motor deficit. \\
\hline 12 & Spine & Lumbar spinal stenosis & Failure to solve the symptoms, CSF Leak. \\
\hline 13 & Spine & Lumbar spinal fracture & $\begin{array}{l}\text { Failure to solve the symptoms, multiple surgeries, CSF leak, } \\
\text { prosthesis failure. }\end{array}$ \\
\hline 14 & Spine & Lumbar disk herniation & Failure to solve the symptoms \\
\hline 15 & Spine & Lumbar disk herniation & Failure to solve the symptoms, novel motor deficit \\
\hline 16 & Spine & Spine Infection & Unexpected negative outcome: parental death. \\
\hline
\end{tabular}

Abbreviation: CSF, cerebrospinal fluid.

old. In addition, it was noted that the majority of the applicants (70\%) were between 49 and 59 years old; and in one case the reading of the exordial did not allow the identification of the age of the patient.

As to gender, 7 authors were male (43\%) and 9 were female (57\%). The marital status of the applicants was thus identified: 12 (75\%) declared themselves as married, 2 widowers (12.5\%), 1 divorced (6.25\%) and 1 single (6.25\%).

Information about the educational profile of the authors was extracted as follows: basic level, that is, complete or incomplete elementary school, corresponded to 3 authors (18.75\%); secondary level - complete or incomplete high school - in 4 (25\%); higher level, characterized as graduate or postgraduate university, in 6 cases (37.5\%). In addition, 1 applicant declared to be illiterate (6.25\%) and the exordial did not bring any information that would allow a conclusion regarding the level of education in 2 of them (12.5\%).

As for the professional activity of the applicants, two teachers and two public servants were noted. The rest were: secretary, lawyer, banker, janitor, telephone technician staff, retired, security, military police officer. In one case the author reported as having no profession ("home worker") and in another there was no information regarding the professional activity performed.

Based on the set of information regarding monthly income and educational level, the socioeconomic level of each author, based on the Brazilian Economic Classification Criteria, was formulated by the Brazilian Association of Research
Companies (ABREP, in the Portuguese acronym). ${ }^{10}$ We consider for this research the criteria established in 2018. Social statements are graded based on objective data, which include the family income and the degree of education of the head of the family. In this way, the population can be classified as Class A (family income $>23,345.11$ reais), B (B1 and B2, income between 5,363.19 and 23,345.10 reais), $C$ ( $C 1$ and $C 2$, income between $1,691.44$ and 5,363.18 reais), $D$ (708.19 to $1,691.43)$ and $E(<708.19$ reais). In the present study, it was possible to conclude the social extract of the applicants as follows: Class A in one case (6.25\%), Class B in 7 (43\%), Class C in 3 (18\%) and Class D in 1 (6.25\%). In 2 cases (12.5\%), the data contained were insufficient to conclude the social statement of the claimant.

Regarding the diagnosis that motivated the treatment and that gave cause to the lawsuit, it was observed that the majority of the processes resulted from complications occurred in spine surgeries (12 cases, 75\%). In addition, these actions were also motivated by diseases classified as tumor ( 2 cases, $12.5 \%$ ), functional ( 1 case, $6.25 \%$ ) and peripheral nerve (1 case, $6.25 \%$ ). Regarding the etiological diagnosis of each case, - Table 4 summarizes each of them and their respective frequencies. Likewise, - Table $\mathbf{5}$ reports the main reasons alleged by the applicant to justify the initiation of the judicial process and their respective absolute and percentage incidence.

During the observation period, only 1 case per year against neurosurgeons was identified in 2008, 2009, 2010 and 2012. In 2015, there were 3 actions, and in 20163 
Table 3 Data Regarding The Claim $(n=16)$

\begin{tabular}{|c|c|c|c|c|c|c|c|}
\hline Case & Value & $\begin{array}{l}\text { inversion } \\
\text { of the } \\
\text { proof } \\
\text { burden }\end{array}$ & $\begin{array}{l}\text { Justice } \\
\text { Gratuitousness }\end{array}$ & CO-Defendant & $\begin{array}{l}\text { Technical } \\
\text { Assistent }\end{array}$ & Documentation Used As Proof & $\begin{array}{l}\text { Expertise } \\
\text { requested? }\end{array}$ \\
\hline 1 & $1.159 .000,00$ & Yes & Yes & Hospital & No & $\begin{array}{l}\text { Event bulletin, body of the crime } \\
\text { examination, reports from third } \\
\text { parties, medical Records }\end{array}$ & Yes \\
\hline 2 & $1.411 .000,00$ & No & No & Hospital & No & $\begin{array}{l}\text { Medical records, surgical } \\
\text { description, medical report, } \\
\text { extrajudicial notification, } \\
\text { imaging reports, reports from } \\
\text { third parties }\end{array}$ & No \\
\hline 3 & $138.000,00$ & Yes & Yes & Hospital & No & Medical records & No \\
\hline 4 & $30.000,00$ & No & No & $\begin{array}{l}\text { Health } \\
\text { insurance plan }\end{array}$ & No & $\begin{array}{l}\text { Reports from INSS, labor contract, } \\
\text { photos from the surgery, photos } \\
\text { from the removed prosthesis, } \\
\text { reports from third parties }\end{array}$ & No \\
\hline 5 & $685.000,00$ & Yes & Yes & Hospital & No & $\begin{array}{l}\text { Medical records, medical } \\
\text { reports, imaging reports }\end{array}$ & Yes \\
\hline 6 & $1.640 .000,00$ & No & Yes & $\begin{array}{l}\text { Hospital and } \\
\text { clinic }\end{array}$ & No & $\begin{array}{l}\text { Imaging reports, press news, } \\
\text { medical reports, reports from } \\
\text { third parties, medical records }\end{array}$ & No \\
\hline 7 & $400.000,00$ & No & No & None & No & $\begin{array}{l}\text { Medical records, redical reports, } \\
\text { imaging reports, photos from } \\
\text { the removed prosthesis. }\end{array}$ & No \\
\hline 8 & $225.000,00$ & Yes & Yes & $\begin{array}{l}\text { Health } \\
\text { insurance plan }\end{array}$ & No & $\begin{array}{l}\text { Pre- and postoperative EMG } \\
\text { reports, medical reports }\end{array}$ & No \\
\hline 9 & $1.500 .000,00$ & No & Yes & Hospital & No & $\begin{array}{l}\text { Medical records, reports from } \\
\text { third parties, borrowed } \\
\text { evidences, press news. }\end{array}$ & No \\
\hline 10 & $95.000,00$ & No & Yes & Hospital & No & $\begin{array}{l}\text { medical reports, borrowed } \\
\text { evidences, medical Records. }\end{array}$ & Yes \\
\hline 11 & $2.169 .000,00$ & No & Yes & $\begin{array}{l}\text { Other medical } \\
\text { staff }\end{array}$ & No & $\begin{array}{l}\text { Medical records, reports from } \\
\text { INSS, imaging reports, } \mathrm{R} \text { reports } \\
\text { from third parties }\end{array}$ & Yes \\
\hline 12 & $400.000,00$ & No & Yes & $\begin{array}{l}\text { Other medical } \\
\text { staff }\end{array}$ & No & $\begin{array}{l}\text { Reports from third parties, } \\
\text { imaging reports, press news, } \\
\text { surgical description }\end{array}$ & No \\
\hline 13 & $335.000,00$ & No & No & $\begin{array}{l}\text { Other medical } \\
\text { staff }\end{array}$ & No & $\begin{array}{l}\text { Imaging studies, imaging } \\
\text { reports, medical reports, press } \\
\text { news. }\end{array}$ & Yes \\
\hline 14 & $200.000,00$ & Yes & Yes & $\begin{array}{l}\text { Hospital, clinic, } \\
\text { health } \\
\text { insurance plan }\end{array}$ & No & $\begin{array}{l}\text { Imaging reports, medical } \\
\text { report, borrowed evidences, } \\
\text { digital data from the court. }\end{array}$ & Yes \\
\hline 15 & $78.000,00$ & Yes & Yes & None & No & $\begin{array}{l}\text { Medical Reports, health reports, } \\
\text { reports from third parties, } \\
\text { DETRAN reports, receipts of } \\
\text { spending. }\end{array}$ & No \\
\hline 16 & $200.000,00$ & No & Yes & $\begin{array}{l}\text { Hospital, health } \\
\text { insurance plan }\end{array}$ & No & $\begin{array}{l}\text { Event bulletin, imaging data, } \\
\text { medical reports }\end{array}$ & Yes \\
\hline
\end{tabular}

Abbreviations: EMG, electromyography, DETRAN, state traffic department; INSS, Brazilian National Insurance Institute.

litigations were also recorded. In 2017 there were 4 lawsuits filed, and 2 in 2018.

Regarding the indication of codefendants, it was noticed that the inclusion of the hospital where the treatment was performed in the passive pole was noticed in 9 actions (56\%); the indication of the health insurance company was identified as running in 4 cases (25\%); of other medical staff in 3-all of them also neurosurgeons (18.75\%); and of the medical office (clinic) belonging to the claimed neurosurgeon in 2 cases (12.5\%). Two actions (12.5\%) made no mention to any other codefendant; and in 3 cases (18.75\%), there were $>1$ required (hospital + clinic, hospital + health insurance company, hospital +health insurance company + clinic). 
Table 4 Ethiological Diagnosis $(n=16)$

\begin{tabular}{|l|l|l|}
\hline DIAGNOSIS & $\mathbf{n}$ & $\%$ \\
\hline Lumbar disk herniation & 7 & 43 \\
\hline Lumbar spinal stenosis & 4 & 25 \\
\hline Pituitary tumor & 1 & 6.25 \\
\hline Brain glioma & 1 & 6.25 \\
\hline Carpal tunnel syndrome & 1 & 6.25 \\
\hline $\begin{array}{l}\text { Chronic pain } \\
\text { (lumbar inflammatory radiculitis) }\end{array}$ & 1 & 6.25 \\
\hline Spine fracture & 1 & 6.25 \\
\hline Lumbar spinal infection & 1 & 6.25 \\
\hline
\end{tabular}

Table 5 Reasons Alleged For The Outbreak Of The Lawsuit $(n=16)$

\begin{tabular}{|l|l|l|}
\hline Reason & $\mathbf{n}$ & $\%$ \\
\hline Failure to solve the symptoms & 8 & 50 \\
\hline Novel motor deficit & 6 & 37.5 \\
\hline Multiple surgeries & 6 & 37.5 \\
\hline Worsening of symptoms & 5 & 31 \\
\hline Cerebrospinal fluid leak & 5 & 31 \\
\hline Break of prostheses & 4 & 25 \\
\hline Serios unexpected negative outcome & 3 & 18 \\
\hline Inappropriate treatment & 2 & 12.5 \\
\hline Permanent disability & 1 & 6.25 \\
\hline Lack of formal contract & 1 & 6.25 \\
\hline $\begin{array}{l}\text { Lack of information about } \\
\text { the possible risks }\end{array}$ & 1 & 6.25 \\
\hline Wound infection & 1 & 6.25 \\
\hline
\end{tabular}

The value sponsored to the cause, as expressed in the exordial, varied between 30,000.00 reais and 2,169,000.00 reais, with an average of $649,000.00$ reais. It was also observed that in 5 cases, that is, $31 \%$ of the sample, the requested value exceeded 1 million reais. In the same sense, it was observed that $75 \%$ of the cases ( 12 cases) were granted with the benefit of gratuitousness of justice, and that this was not requested in only one exordial. In contrast, the inversion of the burden of proof was only granted in $30 \%$ of the lawsuits, although it was requested in $75 \%$ (12 cases) of the initials. Technical assistants were presented in no case; and there was a request for specialized medical expertise in only $40 \%$ of the initials/exordials analyzed (6 cases).

-Table 6 describes in details the types of documentary evidence that were presented along with the exordial to serve as element of conviction to the allegations reported.

\section{Discussion}

Among the medical specialties, neurosurgery does not correspond to the one with the greatest number of lawsuits. For
Table 6 Documental Evidence Presented At the Moment of the Outbreak of the Lawsuit $(n=16)$

\begin{tabular}{|l|l|l|}
\hline Document evidence & $\mathbf{n}$ & $\%$ \\
\hline Medical records & 10 & 62 \\
\hline $\begin{array}{l}\text { Reports elaborated by third parties } \\
\text { (no medical staff) }\end{array}$ & 10 & 62 \\
\hline Reports from imaging studies & 9 & 56 \\
\hline Medical reports & 7 & 43 \\
\hline Images from imaging studies & 6 & 37.5 \\
\hline Media news & 4 & 25 \\
\hline Evidence borrowed from other lawsuits & 3 & 18 \\
\hline Photo of the removed prostheses & 2 & 12.5 \\
\hline Event bulletin & 2 & 12.5 \\
\hline Description of the durgery & 2 & 12.5 \\
\hline Body of the crime examination & 1 & 6.25 \\
\hline Extrajudicial notification & 1 & 6.25 \\
\hline Reports from the INSS & 1 & 6.25 \\
\hline Labor contract & 1 & 6.25 \\
\hline Photos of the Surgery & 1 & 6.25 \\
\hline EMG reports & 1 & 6.25 \\
\hline Digital data from the court & 1 & 6.25 \\
\hline DETRAN reports & 1 & 6.25 \\
\hline Receipts of expenses with the treatment & 1 & 6.25 \\
\hline
\end{tabular}

Abbreviations: EMG, electromyography, DETRAN, state traffic department; INSS, Brazilian National Insurance Institute.

example, in 1985, the Medical-Legal Institute of Minas Gerais reported that only $4 \%$ of the medical-legal examinations were related to neurosurgery, while the main demand stemmed from cases related to gynecological/obstetric procedures (30\%). ${ }^{11}$ Data analyzed by the TJDFT are concordant, since civil actions in this court were more often filed against obstetrician-gynecologists, general surgeons and plastic surgeons. ${ }^{7}$ On the other hand, STJ data showed that the five specialties with the highest number of actions in this court of appeal were gynecological/obstetrics (27\%), orthopedics (15\%), plastic surgery (10\%), general surgery and neurosurgery (7\%). ${ }^{4}$ The inclusion of neurosurgery among those most judicially sued, along with other specialties that have a much larger number of members in action and with a much higher volume of care, is a highly relevant and worrying fact. Since, in general, the number of cases operated year by year by neurosurgeons is much lower than that of surgeons of the other specialties above cited, this means that, relatively, the number of cases against neurosurgeons is probably percentually higher than that of the other specialties. Therefore, it is concluded that the neurosurgeon presents a much higher risk of suffering a claim for medical error than that of those specialties. This conclusion is in agreement with the American and British literature, which describes that neurosurgeons are more exposed to litigation than doctors of any other specialty. For example, a survey by the American 
Association of Neurological Surgeons (AANS) found that $41 \%$ of American neurosurgeons responded to at least one court case for malpractice. $^{3}$

The international literature dealing with litigation for malpractice in neurosurgery indicates several studies in this respect, especially in the United States, ${ }^{12}$ Great Britain, ${ }^{13}$ France, ${ }^{14}$ China ${ }^{14}$ and Japan. ${ }^{15}$ However, in Brazil, reporting data in this regard is practically inexistent. Thus, it was decided to carry out the present analysis of the initials/exordials of actions against this specialty to begin a more global study of the current circumstances faced by neurosurgeons in Brazilian courts. The methodology used was based on the active search of cases from the database of a civilian society that maintains accredited law offices specialized in medical professional defense. Although we acknowledge that this does not correspond to the ideal methodology because in this way only a sample of the set of processes is analyzed and not the total number of civil actions filed in the country - we believe that it would be practically impossible to have access to all the Brazilian courts to collect data about all of these processes. Thus, a study by sample is more feasible and also allows drawing a profile that approaches the truth, as long as the sample was representative of the studied population. The ANADEM/FUMDAP is one of the main centers for professional medical defense currently active in our country, representing $>27,000$ health professionals $(5.7 \%$ of the total number of doctors registered in Brazil), as well as clinics, hospitals and other specific establishments. Of this total, 122 of them are neurosurgeons, corresponding to $3.8 \%$ of a total of 3,154 neurosurgeons in the country. Therefore, we believe that the sample analyzed is representative of the population of neurosurgeons who have undergone civil lawsuit in the past 10 years and lends itself to the desired analysis.

The first observation of singular importance obtained from this data collection concerns the increasing number of actions of this type that begin each year in Brazil. While at the beginning of our historical series only one civil process could be identified per year, an exponential growth was observed from 2015 onwards. This phenomenon is not restricted to neurosurgery alone (since the increase in the number of malpractice claims has been growing in all specialties), but their reasons have not yet been clarified. This fact has been confirmed from other sources. For example, the TJDFT pointed to an increase in the number of such cases by almost $1,000 \%$ between the years of 2000 and $2015^{7}$; and the STJ noted a $1,600 \%$ increase in the number of appeals arising from lawsuits due to alleged medical malpractice in the same period. ${ }^{4}$ In the case of the STJ, because it is a court of appeal, and therefore the civil actions that arrive there should be understood as exceptions, the data would represent, in fact, only a small fraction of the actual absolute number of actions against physicians in the country. Just as a reason for comparison, data obtained from an analysis by the National Council of Justice (CNJ, in the Portuguese acronym) identified that in the same period, there was a $130 \%$ increase in the number of first instance claims in actions related to the topic "Health," and 85\% in second instance, and of this total of claims, only $2.9 \%$ corresponded to the claim for alleged medical error. ${ }^{23}$

We observed a gender-equivalent distribution of civil lawsuits, with a slightly higher incidence among females (57\%). This same distribution was noted by the STJ study - in which women accounted for $61 \%$ of the lawsuits ${ }^{4}$-and by the TJDFT [62\%]). ${ }^{7}$

Regarding age, the majority was $\sim 50$ years old when the action started. This fact is directly related to the type of disease treated by the neurosurgeons, since it was also identified that almost $90 \%$ of the processes were problems involving spine and brain tumors surgeries. Thus, as these diseases are degenerative or neoplastic in nature, the age group mentioned corresponds to the one with the highest incidence of this type of disease in the general population. Traumatic injury cases, which usually occur in younger people, rarely result in legal claims against physicians, so this age group has hardly been identified in our series. On the other hand, people of very advanced age are generally not candidates for neurological surgeries, also contributing little to the statistics presented. In addition, surgeries in very old patients do not naturally generate high expectations in the family, which could also be due to the absence of this age group in the frequencies of the analyzed processes. The same relationship can be extended to the marital status of the plaintiffs, since individuals in the age group between 50 and 60 are most often married or widowed. Therefore, it was not surprising to observe that almost $90 \%$ of the sample corresponded to those marital status just above cited. The analysis of the age of the claimant is also important in the sense that life expectancy impacts on the compensation amounts due.

As for the profession, the sample is relatively small and does not allow for larger digressions, since the variability was extensive. However, attention was drawn to the fact that it was not possible to determine the profession of the claimants in two initials/exordials, which is possibly related to the low quality of these legal requirements, a fact that reinforces what has already been commented about the "malpractice industry." The evaluation of the level of education of the plaintiffs leads us to the conclusion that the higher the education level, the greater the risk of a surgical complication becoming a litigation. This seems to be in agreement with what we have already discussed about the direct connection between the higher level of patient information and the more demanding that this patient becomes, causing unexpected circumstances to be analyzed in a more rigorous way and, consequently, increasing the risk of a lawsuit. This result also has an impact on those evaluated as to the socioeconomic profile of the applicants, since individuals coming from class B (43\% of the cases) generally have a higher level or at least a second-degree level of education. At the same time, it was noted that $>90 \%$ of the sample corresponds to individuals who have a family income higher than at least 5.000,00 reais per month. However, lawsuits of the size and quality necessary to support a supposed medical error are generally expensive and require a lot of time of dedication from the law offices. The fact that the Brazilian courts frequently assign the benefit of gratuitousness of justice to the 
petitioners (as observed in the present study, $80 \%$ of the cases received this benefit) ends up encouraging some individuals to adventure in this type of process, since the benefit granted practically nullifies the risk of a conviction for failure if the action is dismissed. In our opinion, the offices specialized in defense of health professionals should insist with greater emphasis in fighting against the granting of gratuitous justice, aiming to discourage those individuals with less noble interests in glimpsing the possibility of obtaining easy and practically risk-free financial advantages.

The collected sample demonstrated that two-thirds of the medical prosecutions against neurosurgeons involve spinal surgery. In addition, it has also been noted that diseases involving the lumbar segment of the spine are those most at risk of triggering a civil action, especially when associated with the diagnosis of disk herniation and lumbar spinal stenosis. These results, in fact, correspond to no novelty, since other foreign series also reached the same conclusion. Studies by Rovit et al (280 cases), ${ }^{12}$ Fager ( 275 cases), ${ }^{17}$ Taylor, $^{18}$ Thomas et al (343 cases) ${ }^{19}$ and Elsamadicy et al $(2,131 \text { cases })^{20}$ pointed out to spinal pathologies as the main cause of litigation involving neurosurgeons, accounting for, on average, 40 to $60 \%$ of cases for malpractice. In addition, the study by Fager $^{17}$ concluded that diseases involving the lumbar segment of the spine account for the majority of complaints against these surgeons. In the same way, analyzes of the databases of the National Health Service Litigation Authority (NHSLA) ${ }^{2}$ and of the the American Data Sharing Project of the American Physicians Insurers Association ${ }^{20}$ showed that most of the claims resulted from the treatment of degenerative diseases of the lumbar intervertebral discs, which is in total agreement with our results. A joint analysis of the world literature that deals with this topic allows concluding that the majority of the actions resulted from elective procedures (which was also observed in our cases) and that the chances of being prosecuted for malpractice are not necessarily related directly to the complexity of each case (we observed the same in our study). ${ }^{12}$

However, our series has identified that neurosurgeons have also been sued by occurrence from the treatment of other diseases, such as intracranial and peripheral nerve lesions. With regard to intracranial diseases, it was observed that only complications related to brain tumors surgeries resulted in litigation in our series. These results are in disagreement with the medical literature, since studies in the United States and Britain showed that, in these circumstances, the main causes of neurosurgeon lawsuits stem from cerebrovascular diseases and traumatic brain injuries (which did not cause litigation in any case in our series). The study by Thomas et al. $^{19}$ pointed out claims resulting from these circumstances in $26.8 \%$. The numbers related to the processes of this type are much smaller than those involving the spine because, according to the same author, the patient who undergoes a cranial surgery usually already presents some previous neurological deficit and, therefore, accepts any eventual postoperative dysfunctions in a more resilient way. Peripheral nerve injuries are infrequently associated with professional litigation, just as observed in the present study. In the international literature, only the study by Mukherjee et $\mathrm{al}^{21}$ pointed out a case of this type, among a total of 81 analyzed cases.

The international literature also points out that the main reasons for the outbreak of a legal process due to spinal surgeries are the inappropriate indications of the procedure, worsening of the symptoms (most of them correspond to severe pain), development of novel motor deficit, failure to perform the procedure (wrong level or side, improper installation of prostheses, etc.), and lack of information about involved risks. Local infections are also reported, but less frequently (14\%). ${ }^{15-22}$ The claims related to cranioencephalic trauma generally result from the sequelae of the treatment, whereas the main motivations for damages repair actions in cases of cerebrovascular diseases are the failure to diagnose an aneurysm or an arteriovenous malformation, the nonidentification of sentinel bleeding, vessel rupture during endovascular procedures, or treatment sequelae. ${ }^{17}$ The analysis of our results is in line with the world literature, because we observed that the main reasons that led the patient to seek justice in Brazil were related to problems in resolving their complaints, such as failure to resolve the pain or even worsening it (usually due to multiple surgeries or complications related to implanted prostheses), as well as the development of some type of unexpected motor deficit following the surgical procedure. The development of some unexpected serious complications was the main reason for lawsuits involving intracranial diseases. The study conducted by the STJ identified that the main reasons for the lawsuits against physicians were related to death or irreversible neurological sequelae, regardless of the specialty. ${ }^{4}$ However, we were struck by the high number of situations in which the applicant accused the surgeon of error due to the development of a postoperative cerebrospinal fluid leak. As it is known, the occurrence of a CSF leak does not characterize a surgical technical error, but it is an eventual surgical complication. The fact that the CSF leaks motivates one-third of the processes in Brazil and is not even mentioned in foreign claims, reinforces the idea already discussed about the fragility of some initials/exordials, caused in particular by the "malpractice industry" that has settled in our country.

The values that the authors considered to be fair to repair the alleged damage, as we have presented, were extremely varied. This issue is basically related to the indication of codefendants in the course of the process. What we noticed was that, in general, on the rare occasions when the surgeon was the only defendant cited in the lawsuit ( 2 cases), the indemnity values were lower than when other codefendants were cited. In our study, it was observed that in the majority of the times other characters who participated in the treatment of the patient were also called to justice, especially the hospital where the act was performed (56\%) and the health insurance company (25\%) that authorized and paid for the procedure. In some cases, the value of the cause has reached astronomical sums, such as $>2$ million reais, which was observed especially in a process in which a group of neurosurgeons was quoted jointly in the passive pole. The TJDFT analyzed this issue in 2015 and concluded that the option to 
prosecute, in addition to the surgeon, also its "employer" (from the plaintiff's point of view, of course), is a form used by lawyers of the plaintiff to guarantee some more robust indenizations. ${ }^{7}$ However, this ultimately complicates the situation for the physician because, in the event of conviction, the hospital or the health insurance company will also eventually sue the professional in the form of a regressive action, which was observed in a case in our series . The STJ study pointed out that, responding jointly with the physician, other legal entities were included in the passive pole in $56 \%$ of the cases, ${ }^{4}$ especially the hospital where the surgery was performed (43\%); and in the TJDF study, this association in passive litigation was noticed in $60 \%$ of the cases. ${ }^{7}$

The gratuitousness of justice is a procedural institute that allows exemption in the payment of procedural costs, and is expressly foreseen in article 98, paragraph 1, of the Brazilian Code of Civil Process, which may be pleaded to the judge both at the time of the initial action and in the course of the claim, however conditioned to the existence and maintenance of the state of hyposufficiency of the candidate. The data obtained in this epidemiological survey concern that almost all of the claimants requested this benefit, regardless of the fact that the majority of the individuals in the sample could, in theory, bear the costs of the action (we remember that in more than half of the cases, the authors came from Classes A and B, with monthly income much higher than $5.000,00$ reais). Still, for those who requested the benefit, the Judge granted it $80 \%$ of the time. At this point, it is also interesting to note that the study conducted by the $\mathrm{CNJ}$ that analyzed health demands in Brazil identified that only $20 \%$ of the authors presented elements that would indicate their economic hyposufficiency, ${ }^{23}$ a fact that is in broad agreement with the data we observed with respect to the subgroup of neurosurgeon trials.

On the other hand, the situation was different in relation to the reversal of the burden of proof. Let's see: by the rule, the burden of proving the damage falls on whoever claims it. However, if the magistrate understands that the patient (who is a lay person) faces difficulties to prove his or her statements, he/she may reverse the onus probandi, imputing to the physician the obligation to bring the elements that demonstrate that he/she acted within the precepts of lex artis. ${ }^{1}$ In the lawsuits analyzed in our study, lawyers of the interested party requested the reversal of the burden in most of the cases, but the judge accepted the request in only one third of them. In our opinion, the characterization of "technical hyposufficiency," which was used as a basis for requesting this benefit to the magistrate in all cases of our series, would cease to make sense if the applicant indicated a specialist technical assistant to help him in the application. Thus, this fact would explain why there was no indication of a technical assistant in the exordial in any of the analyzed processes. The indication of this character in a later procedural moment was not object of analysis of the present study.

Finally, we will draw some comments on the documents submitted along with the exordial to provide some supporting background to the allegations. The main evidence presented was restricted to documents in the possession of the applicant or of easy access, such as medical records (or parts thereof) and medical reports (whether formulated by the requested professional or by third parties). In no case, data of technical nature produced by the active pole demonstrating that the surgeon acted with malice, recklessness or negligence were presented. Specialized reports demonstrating the technical error were not collected from any of the processes analyzed, even though none of the applicants indicated a technical assistant, who would be the only professional with the capacity to identify this evidence. Thus, everything in the exordials/initials were no more than interpretations and conclusions of the authors regarding the treatment to which they were submitted, without any technical support. The attached documents, in the majority of cases, basically served much more to report the adopted medical conduct than to demonstrate an alleged error committed by the professional. Thus, it is necessary to make some considerations regarding the professional defense based on these observations. A) The medical record is often used as supposed evidence against the doctor. Therefore, it is suggested to maintain a high level of records of all actions related to the conduction of the clinical case, besides including the maximum of relevant information (especially those related to possible complications), practicing a Defensive Medicine. A thorough and well-organized medical record usually becomes the best defense weapon of the surgeon, even when the prosecutor believes it is an evidence of the error. B) The neurosurgeon should take extra care when writing medical reports, always limiting himself to report facts in the shortest and most accurate possible way, but at the same time avoiding expressing personal opinions, especially regarding the quality of the provided care. This applies to cases where he/she have acted as the primary surgeon, as well as when called upon to comment on surgeries made by others. C) The demonstration that there was no malpractice depends mainly on the translation of absolutely technical medical issues into legal terms that can be understood and evaluated by the magistrate. Thus, the participation of the neurosurgeon in assisting the lawyer in the process of his/her defense is indispensable, providing the scientific material necessary to demonstrate absence of guilt or, at least, to refute the causal link. If the doctor does not consider himself fit enough to do so, he/she must indicate an experienced technical assistant. The good use of technical-scientific data is one of the best ways to prove the innocence of the professional and must be thoroughly used. Even because, in general, the opposite party does not look for this type of evidence, since it is known that most of the medical literature data will end up not being favorable to the accuser. This statement is clearly demonstrated when we note in the present study that only $40 \%$ of the authors requested specialized medical expertise at the time of the presentation of the civil procedure initiative, corroborating the importance of this type of evidence to the conclusion by the real truth.

\section{Conclusions}

The data obtained in the present study allow us to conclude that the number of civil lawsuits against Brazilian 
neurosurgeons, motivated by supposed malpractice, has increased considerably in the last decade. The most common profile of the authors of this type of judicial process are married individuals, around the age of 50 years old, who completed at least high school (that is, with a reasonable degree of education) and with a socioeconomic level mainly from the extract classified as Class B. Spinal degenerative diseases, especially those of the lumbar segment, are responsible for the main cause of neurosurgeon processes; being the failure to resolve the complained pain (or its worsening) and the postoperative development of an unexpected motor deficit the main reasons alleged for the outbreak of the litigation. The average amount of the sponsors requested is $650,000.00$ reais, and codefendants are included in the passive pole in most of the actions, especially the hospital where the surgery was performed. Most of the time, the magistrate grants the benefit of gratuitousness of justice to the author, but the decision of inversion of the burden of proof is not the rule. Finally, the main documentary evidence presented by the applicant is the medical record (or parts thereof) and medical reports drawn up by the defendant him/herself or by third parties. The requisition of expert evidence did not prove to be a strategy frequently used by the patrons of the applicants

\section{Conflict of Interests}

The authors have no conflict of interests to declare.

\section{References}

1 Oliveira MMR. Erro Médico - visão jurídica. In: Epiphanio EB, Vilela JRPX (eds). Perícias Médicas. Teoria e Prática. Rio de janeiro: Guanabara-Koogan; 2009:315-327

2 Hamdan A, Strachan RD, Nath F, Coulter IC. Counting the cost of negligence in neurosurgery: Lessons to be learned from 10 years of claims in the NHS. Br J Neurosurg 2015;29(02):169-177

3 Nahed BV, Babu MA, Smith TR, Heary RF. Malpractice liability and defensive medicine: a national survey of neurosurgeons. PLoS One 2012;7(06):e39237

4 Canal R. Decisões sobre Erro Médico no STJ. Anadem Website. Updated in April 15 2015. Available at: http://anadem.org.br/site/ decisoes-sobre-erro-medico-no-stj/

5 Jena $A B$, Seabury S, Lakdawalla $D$, Chandra A. Malpractice risk according to physician specialty. N Engl J Med 2011;365(07):629-636

6 Romero ADCB. Professional Practice and Neurosurgery: what every neurosurgeon should know about malpractice. Braz Neurosurg 2018;37(04):309-316
7 Gomes TR, Delduque MC. O erro médico sob o olhar do judiciário: uma investigação no Tribunal de Justiça do Distrito federal e Territórios. Cad Ibero-Am Dir Sanit 2017:72-85

8 Fujita RR, Santos IC. Denúncias por erro médico em Goiás. Rev Assoc Med Bras (1992) 2009;55(03):283-289

9 Ausman JI. Medico-legal aspects of neurosurgical practice. Surg Neurol 2003;59(05):345-347

10 ABEP. Critérios de Classificação Econômica Brasil. Available at http://www.abep.org. Acessed in March 312019.

11 Epiphanio EB. A perícia no erro médico. In: Epiphanio EB, Vilela JRPX (eds). Perícias Médicas. Teoria e Prática. Rio de janeiro: Guanabara-Koogan; 2009:329-335

12 Rovit RL, Simon AS, Drew J, Murali R, Robb J. Neurosurgical experience with malpractice litigation: an analysis of closed claims against neurosurgeons in New York State, 1999 through 2003. J Neurosurg 2007;106(06):1108-1114

13 Steele L, Mukherjee S, Stratton-Powell A, Anderson I, Timothy J. Extent of medicolegal burden in neurosurgery - An analysis of the National Health Service Litigation Authority Database. Br J Neurosurg 2015;29(05):622-629

14 Emery E, Balossier A, Mertens P. Is the medicolegal issue avoidable in neurosurgery? A retrospective survey of a series of 115 medicolegal cases from public hospitals. World Neurosurg 2014;81(02):218-222

15 Zhang ZY, Yao Y, Zhou LF. To err is human-medicolegal issues and safe care in neurosurgery. World Neurosurg 2014;81(02): 244-246

16 Nagashima H, Wada Y, Hongo K. Trend of Malpractice Litigation against Neurosurgeons in Japan: An Analysis of Disclosed Database by Courts in Japan from 2001 through 2015. Neurol Med Chir (Tokyo) 2017;57(08):426-432

17 Fager CA. Malpractice issues in neurological surgery. Surg Neurol 2006;65(04):416-421

18 Taylor CL. Neurosurgical practice liability: relative risk by procedure type. Neurosurgery 2014;75(06):609-613, discussion 613

19 Thomas R, Gupta R, Griessenauer CJ, et al. Medical Malpractice in Neurosurgery: A Comprehensive Analysis. World Neurosurg 2018;110:e552-e559

20 Elsamadicy AA, Sergesketter AR, Frakes MD, Lad SP. Review of Neurosurgery Medical Professional Liability Claims in the United States. Neurosurgery 2018;83(05):997-1006

21 Mukherjee S, Pringle C, Crocker M. A nine-year review of medicolegal claims in neurosurgery. Ann R Coll Surg Engl 2014;96(04): 266-270

22 Oliveira MRM, Deluque MC, Sousa MF, Mendonça AVM. Judicialização da saúde: para onde caminha as produções científicas? Saúde Debate $2015 ; \cdots: \cdots: 39$

23 Instituto de Ensino e Pesquisa. Judicialização da Saúde no Brasil: Perfil das Demandas, Causas e Propostas de Solução. Relatório Analítico Propositivo - Justiça Pesquisa 2019;1:1-174 